Research article

Open Access

\title{
Basic fibroblast growth factor and vascular endothelial growth factor serum levels in breast cancer patients and healthy women: useful as diagnostic tools?
}

\author{
Anna Maria Granato ${ }^{1}$, Oriana Nanni ${ }^{1}$, Fabio Falcini², Secondo Folli ${ }^{3}$, Gabriella Mosconi ${ }^{4}$, Franca \\ De Paola ${ }^{5}$, Laura Medri ${ }^{5}$, Dino Amadori² and Annalisa Volpi ${ }^{2}$
}

\begin{abstract}
${ }^{1}$ Istituto Oncologico Romagnolo, Forli, Italy
${ }^{2}$ Department of Medical Oncology, Division of Oncology and Diagnostics, Pierantoni Hospital, Forli, Italy

${ }^{3}$ Breast Surgery Unit, Department of Thoracic Surgery, Morgagni Hospital, Forli, Italy

${ }^{4}$ Blood Transfusion Service, Division of Oncology and Diagnostics, Morgagni Hospital, Forli, Italy

${ }^{5}$ Pathology Unit, Division of Oncology and Diagnostics, Pierantoni Hospital, Forli, Italy
\end{abstract}

Corresponding author: Annalisa Volpi (e-mail: res.onco@ausl.fo.it)

Received: 11 Sep 2003 Revisions requested: 21 Oct 2003 Revisions received: 30 Oct 2003 Accepted: 4 Nov 2003 Published: 25 Nov 2003

Breast Cancer Res 2004, 6:R38-R45 (DOI 10.1186/bcr745)

(c) 2004 Granato et al., licensee BioMed Central Ltd (Print ISSN 1465-5411; Online ISSN 1465-542X). This is an Open Access article: verbatim copying and redistribution of this article are permitted in all media for any purpose, provided this notice is preserved along with the article's original URL.

\begin{abstract}
Introduction The aim of the present study was to analyze the relationship between the expression of vascular endothelial growth factor (VEGF) and basic fibroblast growth factor (bFGF) in breast cancer cells and the corresponding serum levels in individual patients. The study also evaluated the potential of serum levels of the two growth factors as diagnostic markers in a case-control study.
\end{abstract}

Methods VEGF expression and bFGF expression were determined in 62 and 63 tumor samples, respectively. Serum VEGF and bFGF levels were determined in 54 and 65 healthy women and in 69 and 73 breast cancer patients, respectively, using a quantitative sandwich enzyme immunoassay technique.

Results A direct correlation was observed between VEGF expression and bFGF expression in individual tumors
$(P=0.001)$ and between serum levels $(P=0.038)$ in individual patients, but not between tumor cell expression and the corresponding serum level for either growth factor. Median values of serum levels in healthy women and breast cancer patients were not different for VEGF $(P=0.055)$, but were significantly different for bFGF $(P<0.001)$. The receiver operating characteristic curve identified a serum bFGF concentration of $1.0 \mathrm{pg} / \mathrm{ml}$, with $84.9 \%$ sensitivity and $63.1 \%$ specificity, as the best cut-off value to discriminate between healthy women and breast cancer patients. An agebased subgroup analysis showed that serum values of patients older than 70 years of age mainly contributed to the high accuracy.

Conclusions Our data repropose bFGF as a noninvasive diagnostic tool for breast cancer.

Keywords: breast cancer, diagnostic tool, growth factors, serum levels

\section{Introduction}

A large body of studies has shown that endothelial growth factors involved in neo-angiogenesis are largely responsible for or associated with tumor progression and spread. The activation of endothelial cells during tumorigenesis has been defined as the result of the locoregional imbalance between pro-angiogenic and anti-angiogenic factors [1].
Vascular endothelial growth factor (VEGF) and basic fibroblast growth factor (bFGF) are two heparin-binding molecules with potent angiogenic properties both in vivo and in vitro. VEGF comprises four alternative splicing variants that exert a similar activity on endothelial cell proliferation, on in vitro migration and on in vivo permeability. VEGF-soluble proteins bind to two specific tyrosine-kinase receptors, VEGFR-1 (flt-1) and VEGFR-2 (flk-1/KDR), 
which are expressed preferentially in endothelial cells. bFGF is the most widely investigated member of the fibroblast growth factor family. In normal tissue bFGF is present in basement membranes and in the subendothelial extracellular matrix of blood vessels, and stays membranebound as long as there is no signal peptide. In particular, it has been hypothesized that, during both wound healing of normal tissues and tumor development, the action of heparan sulfate degrading enzymes activates bFGF, thus mediating the formation of new blood vessels $[2,3]$.

Higher VEGF and bFGF levels have been found in the serum and urine of patients with different tumor types than in healthy individuals [4-7], and in the serum of patients with metastatic disease than in those with localized disease $[8,9]$. Some studies in patients with breast cancer have investigated the potential of serum VEGF and bFGF levels for diagnostic purposes [5-7,9,10] or for monitoring the clinical course of disease [11-14]. A decrease in VEGF serum levels $[5,8,15]$ and a tendency of VEGF to increase after breast cancer surgery [16] have been reported. These controversial results could perhaps be ascribed to the lack of standardization of the pre-analytical phase related to the serum separation time and the clotting temperature, which can influence platelet activation and, consequently, compromise reliability and reproducibility of the determinations [15,17-19].

Very little information is available for bFGF with respect to platelet activation $[20,21]$. There is some evidence of the potential of its level in serum for disease monitoring [11-13], and only one group has investigated its role in the early detection of breast cancer [6].

In the present study, we analyzed the relationship between the expression of VEGF and bFGF in breast cancer cells and the corresponding serum levels in individual patients. We also aimed to define the potential of serum levels of the two growth factors as diagnostic markers in a casecontrol study.

\section{Materials and methods Case series}

The study was conducted on healthy women and on patients with breast cancer. Most of the patients were recruited from individuals attending the Screening Program run by the Prevention Unit of the Medical Oncology Department of Pierantoni Hospital, and all of the women were older than 50 years of age (range, 51-92 years; median, 67 years). All patients had histologically confirmed breast cancer.

The control group comprised women who were free from any disease associated with an increased angiogenic activity such as diabetic retinopathy, heart disease or lung disease, which could affect VEGF levels and, possibly,
bFGF levels. Healthy women ranged in age from 51 to 77 years, with a median age of 60 years.

The study was examined and approved by the Ethics Committee of the Local Health and Social Services (Azienda USL, Forli) in accordance with the ethical standards laid down in the 1964 Declaration of Helsinki. Written informed consent was obtained from all the women participating in the study.

Growth factors were determined in the tumor and in the serum. Specifically, VEGF and bFGF expression was determined in 62 and 63 tumor samples, respectively. Serum VEGF and bFGF levels were determined in 54 and 65 healthy women, and in 69 and 73 breast cancer patients, respectively.

\section{Immunohistochemical determinations}

Tumor tissue removed during surgery was fixed in neutral buffered $10 \%$ formalin and embedded in paraffin. Fourmicrometer sections of the histologically confirmed tumor samples were mounted on positive-charged slides (BioOptica, Milan, Italy), deparaffinized with xylene, rehydrated, and the endogenous peroxidase activity blocked by $3 \%$ hydrogen peroxide solution.

VEGF expression was determined using a polyclonal antibody that specifically reacts with isoforms $121,165,189$, and 206 (Biogenex, San Ramon, CA, USA). bFGF expression was determined using a monoclonal antibody that reacts with the bFGF $18-24 \mathrm{kDa}$ isoforms (Transduction Laboratories, Lexington, KY, USA). Expression of the estrogen receptor (ER) and of the progesterone receptor (PgR) was determined using 1D5 and 1A6 monoclonal antibodies, respectively (Biogenex).

VEGF, bFGF, ER, and PgR antigen retrieval was performed by microwaving at $75 \mathrm{~W}$ for $15 \mathrm{~min}$ in $10 \mathrm{mM}$ citrate buffer $(\mathrm{pH} 6.0)$ followed by cooling at room temperature for at least $20 \mathrm{~min}$. The sections were then treated for non-specific binding with $3 \%$ bovine serum albumin in PBS for $20 \mathrm{~min}$, after which they were incubated for 1 hour at room temperature with prediluted polyclonal antiVEGF antibody or monoclonal anti-ER and anti-PgR antibodies or anti-bFGF monoclonal antibody diluted 1:100 in PBS. Positive control slides (HL-60, K562, and HeLa tumor cell lines for VEGF and bFGF, and normal breast tissue for $\mathrm{ER}$ and $\mathrm{PgR}$ ) were stained in parallel with the antibodies. The sections were washed with PBS, incubated with universal biotinylated secondary antibody, rinsed in PBS, and incubated with streptavidin-peroxidase conjugate (LSAB+kit; DAKO Corporation, Carpinteria, CA, USA) for $15 \mathrm{~min}$. Sections were rinsed again in PBS, and antibody binding was detected by staining with diaminobenzidine/hydrogen peroxidase chromogen solution (DAB+liquid substrate-chromogen solution; DAKO 
Corporation). Finally, sections were rinsed in deionized water, were counterstained blue by Mayer's Hemalum, and were mounted in Eukitt (Bio-Optica).

VEGF and bFGF expression was evaluated at a light microscope $(200 \times)$ by two independent observers (AMG and LM). Immunoreactivity was expressed as the percentage of the immunopositive area in relation to the total area of invasive neoplastic tissue of the whole section. ER and $\mathrm{PgR}$ analysis was performed by an image analyzer system (CAS 200; Becton Dickinson, San Jose, CA, USA) and expressed as already described.

\section{Immunoassay}

Peripheral venous blood was collected in sterile test tubes (Vacutainer System; Becton Dickinson), left to coagulate at $4^{\circ} \mathrm{C}$ for $30 \mathrm{~min}$, centrifuged at $2000 \times \mathrm{g}$ for $10 \mathrm{~min}$, and then stored in aliquots at $-70^{\circ} \mathrm{C}$ for a maximum of 1 month.

VEGF and bFGF levels were determined using a quantitative sandwich enzyme immunoassay technique (Quantikine; R\&D System, Minneapolis, MN, USA) and all samples were tested in duplicate. Briefly, $100 \mu$ l assay diluent and 100 or $150 \mu \mathrm{l}$ serum sample for VEGF and bFGF, respectively, or scalar concentrations of VEGF $(15.6,31.2,62.5,125,250,500,1000$ and $2000 \mathrm{pg} / \mathrm{ml})$ and bFGF $(0.5,1,2,4,8,16,32$ and $64 \mathrm{pg} / \mathrm{ml})$ were added to each well of a microtiter plate precoated with mouse antihuman VEGF or mouse antihuman bFGF monoclonal antibody. Plates were incubated at room temperature for 2 or 3 hours for VEGF and bFGF, respectively. The wells were then washed to remove unbound VEGF or bFGF, supplemented with $200 \mu$ l enzyme-linked anti-VEGF or anti-bFGF polyclonal antibodies and incubated for 2 hours at room temperature. The wells were washed again, supplemented with antibody-linked enzyme substrates, and left for $25 \mathrm{~min}$ at room temperature. For bFGF assay only, an amplifier solution was added and the reaction was prolonged for $25 \mathrm{~min}$.

After the addition of $50 \mu \mathrm{l}$ stop reagent (2M sulphuric acid), the color intensity in each well was measured at $450 \mathrm{~nm}$ for VEGF and at $490 \mathrm{~nm}$ for bFGF using a spectrophotometer (Medical System, Genoa, Italy). The optical density found in the serum samples was compared with a standard curve of VEGF and bFGF concentrations and was quantified. The coefficient of linearity, which shows the linear correlation between measured absorbance and known amounts of standards, was at least 0.9 for both bFGF and VEGF. The minimum detectable concentration ranged from 0.05 to $0.56 \mathrm{pg} / \mathrm{ml}$ for bFGF and was less than $9 \mathrm{pg} / \mathrm{ml}$ for VEGF, as quoted by the manufacturer.

With regard to intra-assay reproducibility, the determina- duplicate and were repeated when the coefficient of variation (CV) exceeded 15\%. The highest disagreement between the pair values was observed for low levels of the growth factors. Overall, the CV was less than 15\% in 85\% of cases for either VEGF (105 out of 123 samples) or bFGF (117 out of 138 samples). The CV was less than $10 \%$ in $76 \%$ of cases for VEGF and in $68 \%$ of cases for bFGF.

Assessment of interassay reproducibility was made by calculating the CV for growth factor levels of serum samples from five individuals run in quintuplicate. The CV for VEGF determinations ranged from $4.9 \%$ to $9.5 \%$, and that for bFGF from $3 \%$ to $13.3 \%$. In consideration of the low serum concentrations of bFGF and of the fact that the tests were carried out manually, we considered a CV higher than 10\% but lower than 15\% acceptable.

\section{Statistical analysis}

Nonparametric ranking statistics (median test) were used to analyze the relationship between the percentage of positive tumor cells and the serum levels of VEGF and bFGF, considered as continuous variables, and patient characteristics. Spearman's correlation coefficient was used to investigate the relationship between the two markers in the serum or in the tumor. The relation between VEGF and bFGF serum levels and the presence of breast cancer in the case-control study was analyzed using the median test.

The most accurate cut-off value capable of discriminating between healthy women and cancer patients, in the absence of internationally accepted cut-off values for serum bFGF and VEGF concentrations, was identified using a receiver operating characteristic (ROC) curve analysis. In the ROC curve the true positive rates (sensitivity) were plotted against the false positive rates (specificity) for all classification points. Ninety-five percent confidence intervals were calculated for sensitivity and specificity values.

\section{Results \\ Basic studies}

Vascular endothelial growth factor

The percentage of the tumor immunopositive areas ranged from 5 to 100\% (median, 65\%) and the immunoreaction was limited to the cytoplasm. Tumor immunopositivity was not related to patient age, to tumor size, or to lymph node involvement. Tumor immunopositivity was significantly higher in ductal tumor than in other histologies and, unexpectedly, higher in ER-positive and grade 1-2 tumors than in ER-negative or grade 3 tumors (Table 1).

Serum levels ranged from 22.7 to $953.5 \mathrm{pg} / \mathrm{ml}$ (median, $192.7 \mathrm{pg} / \mathrm{ml}$ ) and were not related to any biological or pathological variable. 


\begin{tabular}{|c|c|c|c|c|c|c|}
\hline & \multicolumn{3}{|c|}{ Tumor VEGF } & \multicolumn{3}{|c|}{ Serum VEGF } \\
\hline & $\begin{array}{l}\text { Number } \\
\text { of cases }\end{array}$ & $\begin{array}{l}\% \text { positive cells } \\
\text { [median (range)] }\end{array}$ & $P$ & $\begin{array}{l}\text { Number } \\
\text { of cases }\end{array}$ & $\begin{array}{l}\text { Serum level }(\mathrm{pg} / \mathrm{ml}) \\
\text { [median (range)] }\end{array}$ & $P$ \\
\hline \multicolumn{7}{|l|}{ Age } \\
\hline $51-70$ years & 40 & $65(10-100)$ & \multirow[b]{2}{*}{0.91} & 43 & $180.5(30.8-768.4)$ & \multirow[b]{2}{*}{0.11} \\
\hline$>70$ years & 22 & $65(5-100)$ & & 26 & $241.5(22.7-953.5)$ & \\
\hline \multicolumn{7}{|l|}{ Histotype } \\
\hline Ductal & 53 & $70(5-100)$ & \multirow{3}{*}{0.02} & 56 & $189.9(30.8-953.5)$ & \multirow{3}{*}{0.71} \\
\hline & & & & & & \\
\hline Others & 9 & $50(10-75)$ & & 13 & $238.4(22.7-456.8)$ & \\
\hline \multicolumn{7}{|l|}{ Tumor size } \\
\hline$\leq 2 \mathrm{~cm}$ & 42 & $70(10-100)$ & \multirow{3}{*}{0.09} & 49 & $193.6(30.8-953.5)$ & \multirow{3}{*}{0.42} \\
\hline & & & & & & \\
\hline$>2 \mathrm{~cm}$ & 20 & $47.5(5-90)$ & & 19 & $144.5(22.7-561.0)$ & \\
\hline \multicolumn{7}{|l|}{ Node status } \\
\hline Node-negative & 30 & $70(15-95)$ & \multirow{3}{*}{0.22} & 34 & $204.4(36.6-768.4)$ & \multirow{3}{*}{0.50} \\
\hline & & & & & & \\
\hline Node-positive & 27 & $60(5-100)$ & & 25 & $144.5(22.7-953.5)$ & \\
\hline \multicolumn{7}{|l|}{ Grade } \\
\hline $1-2$ & 38 & $75(10-100)$ & \multirow{3}{*}{0.05} & 40 & $183.7(30.8-768.4)$ & \multirow{3}{*}{0.348} \\
\hline & & & & & & \\
\hline 3 & 11 & $35(5-90)$ & & 11 & $144.5(36.3-953.5)$ & \\
\hline \multicolumn{7}{|l|}{ Steroid status } \\
\hline ER-positive & 43 & $70(10-95)$ & \multirow{3}{*}{0.05} & 47 & $187.0(30.8-953.5)$ & \multirow{3}{*}{0.45} \\
\hline & & & & & & \\
\hline ER-negative & 10 & $30(5-90)$ & & 10 & $270.8(48.3-768.4)$ & \\
\hline \multirow[t]{2}{*}{ PgR-positive } & 31 & $65(10-95)$ & \multirow{3}{*}{0.72} & 34 & $187.1(30.8-953.5)$ & \multirow{3}{*}{0.70} \\
\hline & & & & & & \\
\hline PgR-negative & 22 & $67.5(5-95)$ & & 23 & $193.6(48.3-674.1)$ & \\
\hline
\end{tabular}

ER, estrogen receptor; $\mathrm{PgR}$, progesterone receptor.

Basic fibroblast growth factor

The percentage of the immunopositive areas varied greatly in the different tumors, from a total absence to positivity over the whole tumor area. In the majority of cases (84\%) positivity was limited to the cytoplasm, and in a minority $(16 \%)$ it was observed in both the nucleus and the cytoplasm of the tumor cells. Moreover, in the contiguous macroscopically normal mammary epithelium, positivity was limited to the cell nuclei of the basal layer of mammary ducts. bFGF tumor expression was similar in the subgroups defined by different clinical, pathological, and hormonal characteristics (Table 2).

Serum levels ranged from 0.3 to $26.6 \mathrm{pg} / \mathrm{ml}$ (median, $2.3 \mathrm{pg} / \mathrm{ml}$ ) and once again values were not statistically different as a function of different pathological and biological variables.
A linear correlation was observed between VEGF and bFGF expression in individual tumors $(P=0.001)$ and between serum levels $(P=0.038)$ in individual patients (Table 3). No correlation was observed between tumor cell expression and the corresponding serum level for either growth factor.

\section{Case-control study}

VEGF serum levels in healthy women ranged from 0 to $707.6 \mathrm{pg} / \mathrm{ml}$, with a median value of $145.7 \mathrm{pg} / \mathrm{ml}$. bFGF serum levels in healthy women varied from 0 to $5.7 \mathrm{pg} / \mathrm{ml}$, with a median value of $0.4 \mathrm{pg} / \mathrm{ml}$.

A considerable overlapping of serum VEGF levels between healthy women and breast cancer patients was observed, and median values were not significantly different $(P=0.055)$. Values in cancer patients exceeded the 


\begin{tabular}{|c|c|c|c|c|c|c|}
\hline & \multicolumn{3}{|c|}{ Tumor bFGF } & \multicolumn{3}{|c|}{ Serum bFGF } \\
\hline & $\begin{array}{l}\text { Number } \\
\text { of cases }\end{array}$ & $\begin{array}{l}\% \text { positive cells } \\
\text { [median (range)] }\end{array}$ & $P$ & $\begin{array}{l}\text { Number } \\
\text { of cases }\end{array}$ & $\begin{array}{l}\text { Serum level (pg/ml) } \\
\text { [median (range)] }\end{array}$ & $P$ \\
\hline \multicolumn{7}{|l|}{ Age } \\
\hline $51-70$ years & 41 & $45(0-90)$ & \multirow{3}{*}{0.25} & 46 & $2.2(0.3-15.1)$ & \multirow{3}{*}{0.40} \\
\hline & & & & & & \\
\hline$>70$ years & 22 & $65(5-100)$ & & 27 & $3.0(0.4-26.6)$ & \\
\hline \multicolumn{7}{|l|}{ Histotype } \\
\hline Ductal & 54 & $55(0-100)$ & \multirow{3}{*}{0.68} & 60 & $2.2(0.3-26.6)$ & \multirow{3}{*}{0.90} \\
\hline & & & & & & \\
\hline Others & 9 & $60(0-85)$ & & 13 & $2.3(0.4-5.2)$ & \\
\hline \multicolumn{7}{|l|}{ Tumor size } \\
\hline$\leq 2 \mathrm{~cm}$ & 43 & $55(5-100)$ & \multirow{3}{*}{0.53} & 51 & $2.3(0.3-26.6)$ & \multirow{3}{*}{0.37} \\
\hline & & & & & & \\
\hline$>2 \mathrm{~cm}$ & 20 & $63(5-100)$ & & 21 & $1.9(0.4-11.1)$ & \\
\hline \multicolumn{7}{|l|}{ Node status } \\
\hline Node-negative & 30 & $63(0-100)$ & \multirow{3}{*}{0.69} & 35 & $2.5(0.3-15.1)$ & \multirow{3}{*}{0.43} \\
\hline & & & & & & \\
\hline Node-positive & 27 & $65(0-100)$ & & 28 & $2.0(0.5-26.6)$ & \\
\hline \multicolumn{7}{|l|}{ Grade } \\
\hline $1-2$ & 38 & $62.5(0-100)$ & \multirow{3}{*}{0.99} & 42 & $2.3(0.3-15.1)$ & \multirow{3}{*}{0.57} \\
\hline & & & & & & \\
\hline 3 & 12 & $60(5-100)$ & & 13 & $3.1(1.5-26.6)$ & \\
\hline \multicolumn{7}{|l|}{ Steroid status } \\
\hline ER-positive & 43 & $45(0-100)$ & \multirow{3}{*}{0.43} & 49 & $2.2(0.3-15.1)$ & \multirow{3}{*}{0.32} \\
\hline & & & & & & \\
\hline ER-negative & 10 & $65(5-95)$ & & 11 & $3.5(1.8-11.1)$ & \\
\hline \multirow[t]{2}{*}{ PgR-positive } & 32 & $38(0-100)$ & \multirow{3}{*}{0.12} & 35 & $2.0(0.4-8.6)$ & \multirow{3}{*}{0.19} \\
\hline & & & & & & \\
\hline PgR-negative & 21 & $70(5-95)$ & & 25 & $2.5(0.3-15.1)$ & \\
\hline
\end{tabular}

ER, estrogen receptor; PgR, progesterone receptor.

Table 3

\begin{tabular}{lcc}
$\begin{array}{l}\text { Correlation between serum and tumor vascular endothelial } \\
\text { growth factor (VEGF) and basic fibroblast growth factor } \\
\text { (bFGF) }\end{array}$ & $r_{\mathrm{s}}$ & $P$ \\
\hline & 0.420 & 0.001 \\
\hline Tumor VEGF versus tumor bFGF & 0.200 & 0.038 \\
Serum VEGF versus serum bFGF & 0.133 & 0.320 \\
Serum VEGF versus tumor VEGF & 0.037 & 0.775 \\
\hline Serum bFGF versus tumor bFGF &
\end{tabular}

$r_{\mathrm{s}}$, Spearman's correlation coefficient.

highest value $(707.6 \mathrm{pg} / \mathrm{ml})$ detected in healthy women in R42
A partial overlapping of bFGF serum levels in healthy women and in breast cancer patients was also observed, but the difference between the median values of the two subgroups was significantly different $(P<0.001)$ (Fig. 1b). Moreover, all values equal to or higher than $6.0 \mathrm{pg} / \mathrm{ml}$ $(8 / 8)$ referred to cancer patients, while the total absence of bFGF in the serum (27/27) was only observed in healthy women.

The ROC curve did not highlight any acceptable concentration of serum VEGF in terms of either sensitivity or specificity (Fig. 2a). Conversely, when calculated using serum bFGF values of healthy women and of breast cancer patients (Fig. 2b), the ROC curve identified a concentration of $1.0 \mathrm{pg} / \mathrm{ml}$, with an $84.9 \%$ sensitivity and a $63.1 \%$ specificity, as the best discriminant (Table 4). For patients older than 70 years of age, a similar sensitivity (77.8\%) and a higher specificity (78.6\%) were observed. 

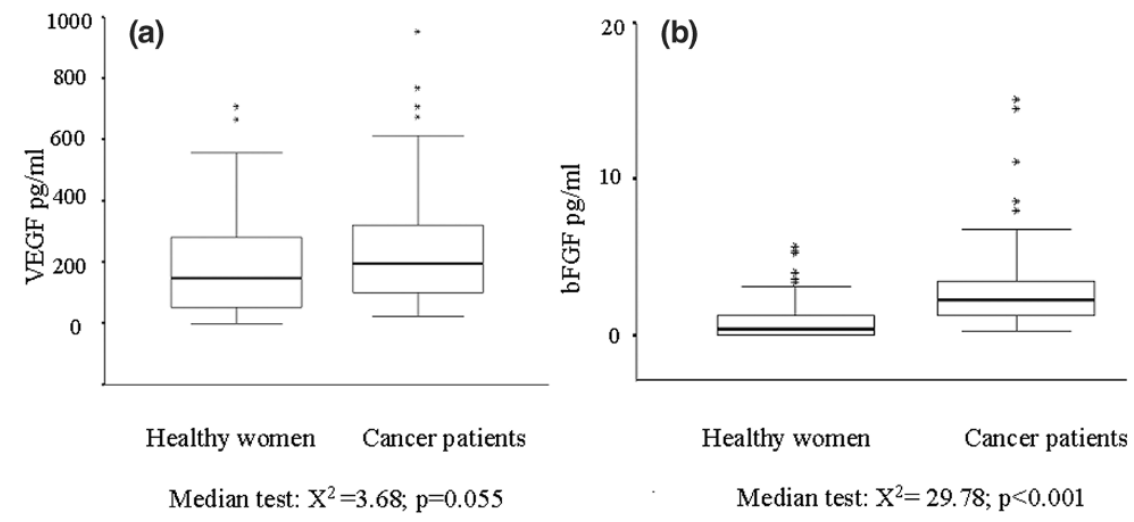

Box plots of (a) vascular endothelial growth factor (VEGF) and (b) basic fibroblast growth factor (bFGF) serum levels. The lower boundary of the box is the 25 th percentile and the upper boundary is the 75 th percentile. The bold line inside the box represents the median. ${ }^{*}$ Cases with values more than 1.5 box lengths from the upper or lower edge of the box (extreme values). The largest and smallest observed values that are not extreme values are also shown (whiskers).

\section{Figure 2}
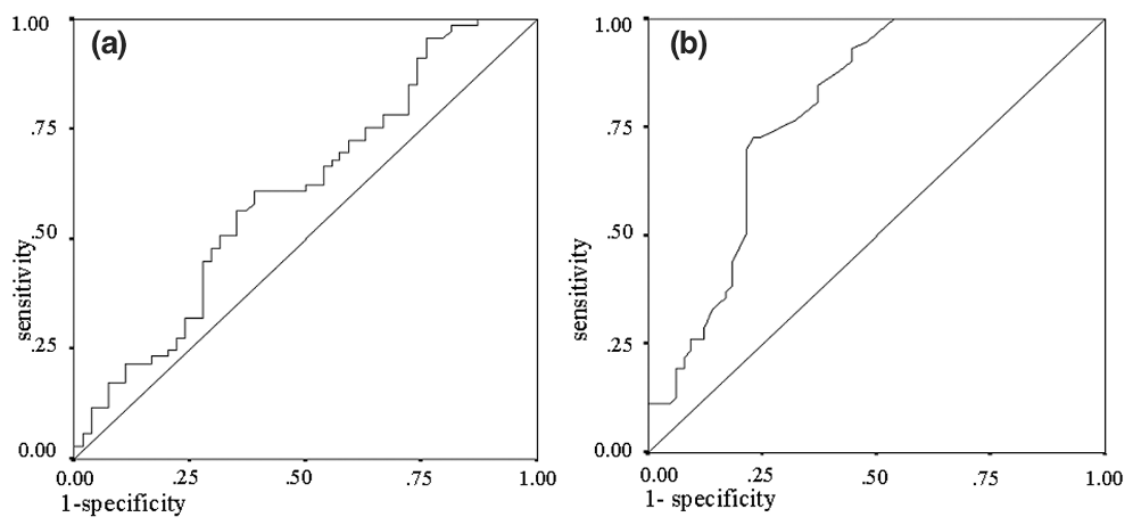

Area under the curve: $0.609(95 \% \mathrm{CI}=0.507-0.710) \quad$ Area under the curve: $0.790(95 \% \mathrm{CI}=0.711-0.869)$

Receiver operating characteristic curve of (a) vascular endothelial growth factor and (b) basic fibroblast growth factor serum levels. $\mathrm{Cl}$, confidence interval.

Table 4

Basic fibroblast growth factor sensitivity and specificity in women older than $\mathbf{5 0}$ years of age*

\begin{tabular}{lccc}
\hline & Number of cases/controls & Sensitivity (\%) & Specificity (\%) \\
\hline Overall series & $73 / 65$ & $84.9(95 \% \mathrm{Cl}, 76.7-93.1)$ & $63.1(95 \% \mathrm{Cl}, 51.4-74.8)$ \\
$51-70$ years old & $46 / 51$ & $76.1(95 \% \mathrm{Cl}, 63.8-88.4)$ & $64.7(95 \% \mathrm{Cl}, 51.6-77.8)$ \\
$>70$ years old & $27 / 14$ & $77.8(95 \% \mathrm{Cl}, 62.1-93.5)$ & $78.6(95 \% \mathrm{Cl}, 57.1-100.0)$ \\
\hline
\end{tabular}

$\mathrm{Cl}$, confidence interval. * Cut-off value, $1.00 \mathrm{pg} / \mathrm{ml}$.

\section{Discussion}

Information on the clinical relevance of VEGF expression and bFGF expression in breast cancer patients is inconclusive. In addition to positive data [22-24] negative results on the prognostic relevance have been reported [25], particularly when their role was assessed according to internationally accepted guidelines in a large series of node-negative breast cancer patients not treated with any 
type of systemic therapy [26]. To exert their potent angiogenic effect, however, these growth factors have to be secreted by tumor cells, and altered amounts are therefore expected to be present in the blood of patients.

In the present study, we found a correlation in individual patients between the expression of VEGF and bFGF in tumor cells as well as between their levels in serum, but not between the expression in tumor cells and the serum concentration of either growth factor. It is also worthy of note that bFGF expression in tumor cells was not correlated with any conventional pathological or biological variable of prognostic relevance and that VEGF expression was not significantly related to tumor size or to nodal involvement. Furthermore, VEGF expression was significantly higher in ductal tumors and, paradoxically, inversely related to the grade and the ER level, as already observed by other authors [15]. It can therefore be concluded that the expression of these growth factors is not closely related to tumor growth and progression, which could justify the negative results on their prognostic relevance.

The question now arises: what point in the preclinical or the clinical tumor lifespan do cancer cells produce angiogenic factors, and when do these become determinant in stimulating and supporting tumor growth? Preliminary but suggestive data have shown that VEGF serum levels of patients with in situ breast carcinoma are comparable with, if not higher than, those detected in the sera of women with primary invasive breast cancer $[7,9]$. This finding was also observed for serum levels of bFGF in a small preliminary series of patients with in situ carcinoma (data not shown). This suggests that the secretion of angiogenic factors might occur in the early phases and might play an important role in preclinical tumor life [27].

To verify the potential of VEGF and bFGF serum levels as noninvasive diagnostic markers, we performed a casecontrol study. Our results seem to indicate that VEGF serum levels are not useful as a diagnostic tool for breast cancer due to the considerable overlapping of the sets of values observed in healthy women and in patients, in agreement with some previous results $[28,29]$ and in contrast with others $[7,9]$. We would like to underline, however, that our data were obtained under strict standardized conditions for the serum separation time and the clotting temperature, both important pre-analytical aspects, since VEGF levels in the serum are known to be largely platelet derived [17-19,30-33]. Our evidence is supported by the negative results on the clinical relevance of VEGF detected in nipple aspirate fluid [27], independent of any platelet activation.

Positive results were conversely observed for bFGF serum levels that, although partially overlapping in healthy women and in patients, showed statistically different median values in the two groups. Moreover, a total absence of bFGF in serum was observed exclusively in healthy women, while values equal to or higher than $6 \mathrm{pg} / \mathrm{ml}$ were found only in breast cancer patients.

The ROC analysis identified a cut-off serum concentration with a high sensitivity and a good specificity to identify breast cancer patients. An age-based subgroup analysis showed that serum values of patients older than 70 years of age contributed largely to this sensitivity and specificity.

Our results are in agreement with those reported by other authors who brought to light the importance of bFGF serum levels in discriminating between healthy women and breast cancer patients. These studies were conducted using a nonstandardized inhouse enzyme immunoassay methodology [6] on a heterogeneous series of patients [11] or on small case-control subgroups [30]. The results from the present study, which was conducted on a large, prospectively planned case-control series, in which all the patients had operable tumors and in which all determinations were carried out under strict standardized and quality-controlled procedures, repropose the usefulness of the bFGF serum level for breast cancer detection.

The determination of serum bFGF represents a simple, inexpensive and noninvasive approach, also when compared with recently proposed nipple aspiration [27], and would seem to be indicated mainly for women older than 70 years of age to whom mammograms and clinical screening are not routinely offered. Moreover, bFGF would seem to have a higher accuracy than other biomarkers such as carcinoembryonic antigen or cancer antigen 15.3, which were proposed for cancer diagnosis some years ago and, albeit not fully validated [34], are now used for monitoring purposes.

\section{Conclusion}

The bFGF serum level is associated with the presence of breast cancer. Its usefulness for the early detection of sporadic cancer, within screening programs, and in monitoring members of high-risk breast cancer families warrants a prospective validation in a confirmatory study.

\section{Competing interests}

None declared.

\section{Acknowledgements}

This work was supported by Istituto Oncologico Romagnolo, Forli, and by the National Research Council (CNR-Progetto Strategico MIUR; grant number 02.00452.ST97), Rome, Italy. The authors would like to thank Prof. Rosella Silvestrini for her invaluable scientific contribution and Gráinne Tierney for editing the manuscript. They also thank Michela Ballardini, Verdiana Papi, Paola Minardi, Giordano Cavina, Franco Monti, and Barbara Piantini for their help.

\section{References}

1. Folkman J: Clinical application of research on angiogenesis. $N$ Engl J Med 1995, 333:1757-1763. 
2. D'Amore PA: Heparin-endothelial cell interactions. Haemostasis 1990, Suppl 1:159-165.

3. Vlodavsky I, Korner G, Ishai-Michaeli R, Bashkin P, Bar-Shavit R, Fuks Z: Extracellular matrix-resident growth factors and enzymes: possible involvement in tumor metastasis and angiogenesis. Cancer Metastasis Rev 1990, 9:203-226.

4. Nguyen $M$, Watanabe $H$, Budson AE, Richie JP, Hayes DF, Folkman J: Elevated levels of an angiogenic peptide, basic fibroblast growth factor, in the urine of patients with a wide spectrum of cancers. J Natl Cancer Inst 1994, 86:356-361.

5. Yamamoto $Y$, Toi M, Kondo S, Matsumoto T, Suzuki H, Kitamura M, Tsuruta K, Taniguchi T, Okamoto A, Mori T, Yoshida M, Ikeda T, Tominaga $T$ : Concentrations of vascular endothelial growth factor in the sera of normal controls and cancer patients. Clin Cancer Res 1996, 2:821-826.

6. Takei Y, M Kurobe, A Uchida, K Hayash: Serum concentrations of basic fibroblast growth factor in breast cancer [letter to the editor]. Clin Chem 1994, 40:1980-1981.

7. Heer K, Kumar H, Read JR, Fox JN, Monson JR, Kerin MJ: Serum vascular endothelial growth factor in breast cancer: its relation with cancer type and estrogen receptor status. Clin Cancer Res 2001, 7:3491-3494.

8. Kraft A, Weindel K, Ochs A, Marth C, Zmija J, Schumacher P, Unger C, Marme D, Gastl G: Vascular endothelial growth factor in the sera and effusions of patients with malignant and nonmalignant disease. Cancer 1999, 85:178-187.

9. Salven $P$, Perhoniemi V, Tykka H, Maenpaa H, Joensuu H: Serum VEGF levels in women with a benign breast tumor or breast cancer. Breast Cancer Res Treat 1999, 53:161-166.

10. Salven $P$, Manpaa H, Orpana A, Alitalo K, Joensuu H: Serum vascular endothelial growth factor is often elevated in disseminated cancer. Clin Cancer Res 1997, 3:647-651.

11. Pichon MF, Moulin G, Pallud C, Pecking A, Floiras JL: Serum bFGF (basic fibroblast growth factor) and CA 15.3 in the monitoring of breast cancer patients. Anticancer Res 2000, 20:1189-1194.

12. Dirix LY, Vermeulen PB, Pawinski A, Prove A, Benoy I, De Pooter C, Martin M, Van Oosterom AT: Elevated levels of the angiogenic cytokines basic fibroblast growth factor and vascular endothelial growth factor in sera of cancer patients. $\mathrm{Br} J$ Cancer 1997, 76:238-243.

13. Sliutz G, Tempfer C, Obermair A, Dadak C, Kainz C: Serum evaluation of basic FGF in breast cancer patients. Anticancer Res 1995, 15:2675-2677.

14. Findeisen R, Albrecht $S$, Richter B, Deutschmann K, Zimmermann T, Distler W: Chemiluminometric determination of tissue polypeptide antigen (TPA), cancer antigen 15-3 (CA 15-3), carcinoembryonic antigen (CEA) in comparison with vascular endothelial growth factor (VEGF) in follow-up of breast cancer. Luminescence 2000, 15:283-289.

15. Adams J, Carder PJ, Downey S, Forbes MA, MacLennan K, Allgar V, Kaufman S, Hallam S, Bicknell R, Walker JJ, Cairnduff F, Selby PJ, Perren TJ, Lansdown M, Banks RE: Vascular endothelial growth factor (VEGF) in breast cancer: comparison of plasma, serum, and tissue VEGF and microvessel density and effects of tamoxifen. Cancer Res 2000, 60:2898-2905.

16. Emilio A, Aranega A, Sevilla M, Parra G, Villarreal V, Viñas J, Alonso L, Ruiz I, Ribelles N, Gonzalez F: Evolution of serum angiogenic growth factor levels after breast cancer surgery [abstract]. ASCO Proc 2000, 19:601.

17. Verheul HM, Hoekman K, Luykx-de Bakker S, Eekman CA, Folman $\mathrm{CC}$, Broxterman HJ, Pinedo HM: Platelet: transporter of vascular endothelial growth factor. Clin Cancer Res 1997, 3:21872190.

18. Webb NJ, Bottomley MJ, Watson CJ, Brenchley PE: Vascular endothelial growth factor (VEGF) is released from platelets during blood clotting: implications for measurement of circulating VEGF levels in clinical disease. Clin Sci (Lond) 1998, 94: 395-404.

19. Banks RE, Forbes MA, Kinsey SE, Stanley A, Ingham E, Walters $C$, Selby PJ: Release of the angiogenic cytokine vascular endothelial growth factor (VEGF) from platelets: significance for VEGF measurements and cancer biology. $\mathrm{Br} J$ Cancer 1998, 77:956-964.

20. Salgado R, Vermeulen PB, Benoy I, Weytjens R, Huget $P$, Van Marck E, Dirix LY: Platelet number and interleukin-6 correlate with VEGF but not with bFGF serum levels of advanced cancer patients. Br J Cancer 1999, 80:892-897.
21. Brunner G, Nguyen H, Gabrilove J, Rifkin DB, Wilson EL: Basic fibroblast growth factor expression in human bone marrow and peripheral blood cells. Blood 1993, 81:631-638.

22. Toi $M$, Inada $K$, Suzuki $H$, Tominaga $T$ : Tumor angiogenesis in breast cancer: its importance as a prognostic indicator and the association with vascular endothelial growth factor expression. Breast Cancer Res Treat 1995, 36:193-204.

23. Faridi A, Rudlowski C, Biesterfeld S, Schuh S, Rath W, Schroder $\mathrm{W}$ : Long-term follow-up and prognostic significance of angiogenic basic fibroblast growth factor (bFGF) expression in patients with breast cancer. Pathol Res Pract 2002, 198:1-5.

24. Visscher DW, DeMattia F, Ottosen S, Sarkar FH, Crissman JD: Biologic and clinical significance of basic fibroblast growth factor immunostaining in breast carcinoma. Mod Pathol 1995 8:665-670.

25. Smith K, Fox SB, Whitehouse R, Taylor M, Greenall M, Clarke J, Harris AL: Upregulation of basic fibroblast growth factor in breast carcinoma and its relationship to vascular density, oestrogen receptor, epidermal growth factor receptor and survival. Ann Oncol 1999, 10:707-713.

26. De Paola F, Granato AM, Scarpi E, Monti F, Medri L, Bianchi S, Amadori D, Volpi A: Vascular endothelial growth factor and prognosis in patients with node-negative breast cancer. Int J Cancer 2002, 98:228-233.

27. Hsiung R, Zhu W, Klein G, Oin W, Rosenberg A, Park P, Rosato E, Sauter E: High basic fibroblast growth factor levels in nipple aspirate fluid are correlated with breast cancer. Cancer $J$ 2002, 8:303-310.

28. Dreisbach L, Cowgill A, Brunn E, Vahedian M, Villar H, Reichlin S, Stopeck A: Random pre-operative VEGF levels are not diagnostic of the presence of breast cancer [abstract]. ASCO Proc 2000, 19:2587.

29. Liu Y, Wang JL, Chang H, Barsky SH, Nguyen M: Breast-cancer diagnosis with nipple fluid bFGF [letter]. Lancet 2000, 356:567.

30. Chung HC, Rha SY, Ahn JB, Shim KY, Yoo NC, Kim JH, Roh JK, Lee KS, Min JS, Kim BS, Kim JJ: Menstrual state should be considered in determining sero-positivity of soluble angiogenic factors in breast cancer. Int $J$ Mol Med 1998, 2:465-470.

31. Wartiovaara U, Salven $P$, Mikkola $H$, Lassila R, Kaukonen J, Joukov V, Orpana A, Ristimaki A, Heikinheimo M, Joensuu H, Alitalo $K$, Palotie A: Peripheral blood platelets express VEGF-C and VEGF which are released during platelet activation. Thromb Haemost 1998, 80:171-175.

32. Mohle R, Green D, Moore MA, Nachman RL, Rafii S: Constitutive production and thrombin-induced release of vascular endothelial growth factor by human megakaryocytes and platelets. Proc Natl Acad Sci USA 1997, 94:663-668.

33. Dittadi R, Meo S, Fabris F, Gasparini G, Contri D, Medici M, Gion $\mathrm{M}$ : Validation of blood collection procedures for the determination of circulating vascular endothelial growth factor (VEGF) in different blood compartments. Int J Biol Markers 2001, 16:87-96.

34. Bast RC Jr, Ravdin P, Hayes DF, Bates S, Fritsche H Jr, Jessup JM, Kemeny N, Locker GY, Mennel RG, Somerfield MR, for the American Society of Clinical Oncology Tumor Markers Expert Panel: $\mathbf{2 0 0 0}$ update of recommendations for the use of tumor markers in breast and colorectal cancer: clinical practice guidelines of the American Society of Clinical Oncology. J Clin Oncol 2001, 19:1865-1878.

\section{Correspondence}

Annalisa Volpi, BSc, Department of Medical Oncology, Pierantoni Hospital, via Forlanini 34, 47100 Forli, Italy. Tel: +39 543 731737; fax: +39543 731736; e-mail: res.onco@ausl.fo.it 